\title{
Countermeasures Analysis of Tourism Development in Hubei Province in Post-Pandemic Era -- Based on SWOT-PEST Model
}

\author{
Zhao Lei ${ }^{1 *}$, Wang Ying ${ }^{2}$ \\ ${ }^{1}$ School of Tourism Management, Wuhan Business School, Wuhan, China \\ ${ }^{2}$ School of Tourism Management, Wuhan Business School, Wuhan, China
}

\begin{abstract}
In the post-pandemic era, tourism industry in Hubei Province has entered a critical period of transformation in the face of post-pandemic development. Based on the matrix model of SWOT-PEST analysis method, in this paper, the strengths, weaknesses, opportunities and threats of tourism development in Hubei Province were analyzed, and reference basis and feasible suggestions were provided for the development of tourism industry in Hubei Province in the post-pandemic era from the political, economic, social and technical aspects.
\end{abstract}

\section{Introduction}

From December 2019 to April 2020, the pandemic of COVID-19 broke out in Wuhan, Hubei Province. The virus spread so fast that it threatened the whole country. At 10 o'clock on January 23, 2020, Wuhan officially closed all its ways out of the city, and the response to public health event was launched across the country, and scenic spots across the country were suspended due to the pandemic. The tourism industry has been greatly affected by the pandemic. Since January 24, all public cultural venues, A-level tourist attractions and travel agencies in Hubei Province had been temporarily closed. The tourism industry was in a state of shutdown, missing the tourism market in the Golden Week of Spring Festival and February. Since the middle and late March, A-level scenic spots in Hubei Province had gradually resumed their operations. The shutdown was an unprecedented blow to the tourism industry, while the resume marked the beginning of the "post-pandemic era". How to develop the tourism industry in Hubei Province after the pandemic? With the national economy hit hard, how to stimulate the tourism consumption in Hubei Province? How to develop the tourism in Hubei Province in the post-pandemic era? In the face of this series of problems, reference basis and feasible suggestions were provided in this paper for the development of tourism industry in Hubei Province in the post-pandemic era.

\section{Construction of SWOT-PEST Matrix for the Development of Tourism in Hubei Province}

The SWOT-PEST matrix for development of tourism in Hubei Province is shown below in Table 1

Table 1 SWOT-PEST matrix for development of tourism in Hubei Province

\begin{tabular}{l|l|l|l|l}
\hline Item & Political factors(P) & Economic factors(E) & Social factors(S) & Technical factor(T) \\
& & & & \\
\hline
\end{tabular}

Corresponding author email: 5943498@qq.com 


\begin{tabular}{|c|c|c|c|c|c|}
\hline \multirow{2}{*}{ 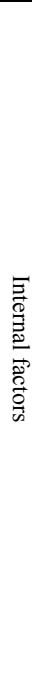 } & $\begin{array}{l}\text { Stre } \\
\text { ngth } \\
\mathrm{s}(\mathrm{S})\end{array}$ & $\begin{array}{l}\text { The state supports the } \\
\text { tourism industry } \\
\text { vigorously, and the } \\
\text { Hubei Government is } \\
\text { also vigorously } \\
\text { developing the tourism } \\
\text { industry. }\end{array}$ & $\begin{array}{l}\text { Hubei has increased } \\
\text { financial support to boost } \\
\text { the development of the real } \\
\text { economy. }\end{array}$ & $\begin{array}{l}\text { Living habits of people } \\
\text { have changed a lot and } \\
\text { the requirements for the } \\
\text { environment have been } \\
\text { raised. } \\
\text { The image of the Hero } \\
\text { City has been promoted, } \\
\text { and Hubei Province has } \\
\text { become more popular. }\end{array}$ & $\begin{array}{l}\text { Hubei Province is an } \\
\text { important hub } \\
\text { connecting the north and } \\
\text { the south of China. } \\
\text { Hubei Province is } \\
\text { speeding up the digital } \\
\text { transformation and } \\
\text { upgrading. }\end{array}$ \\
\hline & $\begin{array}{l}\text { Wea } \\
\text { knes } \\
\text { ses( } \\
\text { W) }\end{array}$ & $\begin{array}{l}\text { The industry structure of } \\
\text { tourism of Hubei } \\
\text { Province is not } \\
\text { reasonable and lacks } \\
\text { reasonable planning and } \\
\text { development. }\end{array}$ & $\begin{array}{l}\text { Hubei's overall economy } \\
\text { suffered a huge impact, and } \\
\text { the tourism industry } \\
\text { suffered heavy losses. }\end{array}$ & $\begin{array}{l}\text { The value of brand } \\
\text { culture of Hubei } \\
\text { Province is low, the } \\
\text { tourism products are } \\
\text { seriously homogenized, } \\
\text { and the distribution of } \\
\text { tourism resources is } \\
\text { uneven. }\end{array}$ & $\begin{array}{l}\text { Imperfect tourism } \\
\text { facilities, poor } \\
\text { accessibility of the } \\
\text { region, and the lack of } \\
\text { tourism talents. }\end{array}$ \\
\hline \multirow{2}{*}{ 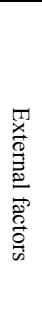 } & $\begin{array}{l}\text { Opp } \\
\text { ortu } \\
\text { nitie } \\
\mathrm{s}(\mathrm{O})\end{array}$ & $\begin{array}{l}\text { Policy support provided } \\
\text { by national and local } \\
\text { governments for tourism } \\
\text { development. }\end{array}$ & $\begin{array}{l}\text { The rapid development of } \\
\text { other industries. }\end{array}$ & $\begin{array}{l}\text { The huge tourism market } \\
\text { of Hubei Province, } \\
\text { convenient transportation } \\
\text { and the change of } \\
\text { people's life concept. }\end{array}$ & $\begin{array}{l}\text { The emergence of 5G } \\
\text { technology, the } \\
\text { development of mobile } \\
\text { technology and the } \\
\text { popularization of } \\
\text { artificial intelligence. }\end{array}$ \\
\hline & $\begin{array}{l}\text { Thre } \\
\text { ats( } \\
\text { T) }\end{array}$ & $\begin{array}{l}\text { The legal system is not } \\
\text { perfect and } \\
\text { corresponding } \\
\text { management and control } \\
\text { is not in place. }\end{array}$ & $\begin{array}{l}\text { The global economy is in a } \\
\text { slump, and restoring the } \\
\text { market economy is a huge } \\
\text { challenge. }\end{array}$ & $\begin{array}{l}\text { Hubei's tourism image is } \\
\text { damaged and the } \\
\text { competition pressure } \\
\text { from other regions is } \\
\text { great. }\end{array}$ & $\begin{array}{l}\text { The imperfection of } \\
\text { digital tourism and } \\
\text { supporting infrastructure } \\
\text { in Hubei Province. }\end{array}$ \\
\hline
\end{tabular}

\section{Tourism Development Strategy of Hubei Province in Post-Pandemic Era}

\section{(I) SE strategies}

Seizing the current economic advantages is the most advantageous opportunity for Hubei Province after the pandemic. The outbreak of the pandemic has hit the tourism industry the hardest, causing many small and medium-sized tourism enterprises to go bankrupt and large tourism enterprises to completely rely on their own financial support. Now in the aspect of tourism, Hubei Province has opened up its post-pandemic economic policies to make it easier for small businesses to borrow money to ride out the crisis. However, in order to fundamentally solve the problems of tourism, we still need to restore the normal state of tourism, drive the activities of the tourism industry, and contribute to the emergence of motivation for tour. That is the most urgent need for the real turnaround of the industry. At present, because of the fear of people and grounding policy during the pandemic, the travel demand was reduced or even completely eliminated. Hubei Province should take advantage of the opportunities, vigorously promote the stories of heroes during the pandemic era, and make people believe the result of the pandemic: Hubei Province is safe enough after the pandemic; although the pandemic started here, it is already over. We should eliminate people's fear of travel in their minds, and create people's demand for travel. At the same time, the favorable economic policies would enable enterprises to launch various programs benefiting the people at the present stage, which would greatly increase people's demand for tourism. For example, the activity of "free of charge for medical staff" launched by many enterprises had been imitated by enterprises all over the country after obtaining high social recognition and praise, which also stimulated the economic recovery and development. In a word, now Hubei Province can take advantage of its current economic advantages to develop a tourism label as the Hero City in the fight against the pandemic. At the same time, it can seize people's travel motivation to drive the growth of people's consumption and vigorously develop the tourism industry in Hubei Province.

(2) WT strategies

1. Improve tourism infrastructure

Faced with the pandemic, we had the opportunity to find out internal weaknesses and improve the upgrading and transformation of Hubei tourism. By attracting various funds and government support, we could increase investment in tourism infrastructure construction. For a long time, infrastructure backwardness has restricted the development of tourism in Hubei. Hubei is not a major province for tourism, and the infrastructure of scenic spots is relatively backward. During the peak tourist season or holidays, due to impassable roads and unreasonable structure, scenic spots are either barely visited or overcrowded. As a result, tourists do not have a good travel experience. While stimulating tourism consumption, the government should increase investment in tourism infrastructure. For example, we can improve the hydro-power, security and sanitary environment in some scenic spots, and improve the accessibility of tourist attractions in northwest region. In order to respond to the post-pandemic era and speed up the 
development of tourism industry, Hubei should not only improve its hard power, but also improve its soft power by building its own brand, thus enhancing its overall appeal. We should seize all opportunities and actively attract various funds to improve diversified tourism. In addition, under the concept of healthy tourism advocated by the state, we should adhere to the local features, develop the popular rural tourism currently, and stimulate the economic development of backward areas so as to realize the all-round development of Hubei tourism.

2. Attach importance to the cultivation of tourism professionals

In recent years, the tourism industry has developed so fast that traditional tourism can no longer meet people's needs. Consequently, the professional qualities of tourism employees have been improved accordingly. However, tourism is also a very comprehensive service industry. In order to realize the transformation and upgrading of tourism in the future, we need not only science and technology but also tourism professionals for support. Therefore, attention should be paid to the cultivation of tourism professionals. In some areas of our country, the requirements for tourism professionals are relatively low, and the cultivation of talents has not been paid attention to. As a result, the quality of tourism development has not been greatly improved. Although there are relevant professional talents that have been cultivated, they cannot catch up with the development speed of tourism industry. It should not be taken lightly regarding how to cultivate a large number of tourism professionals and retain them to make contributions to tourism development.

(3) TS strategies

1. Rebuild tourism images

After the outbreak of the pandemic in Wuhan, people all over the country got into a panic. Tourism has been affected far more seriously than any other industries. In the post-pandemic era, the most pressing issue is to rebuild the tourism images and help people get rid of the fear of traveling to Wuhan. In the past, the tourist destinations in Hubei province were mainly the Yellow Crane Tower and Wudang Mountain scenic spots. After the pandemic, Hubei province needs to strengthen the construction of tourist destinations, and add other new elements to the tourism construction. For example, the new ski resort built in Shennongjia has incorporated the elements of exciting sports. In the post-pandemic era, establishing new tourist attractions can change the old impression of people on Hubei province and reduce people's fear of traveling to Hubei.

2. Accelerate tourism construction and increase the competitiveness of tourism destinations

In addition to building the image of tourism destinations, Hubei also needs to compete with other provinces in tourism destinations. In the post-pandemic era, with the government's policy and economic support, Hubei province needs to speed up tourist construction, develop tourism destinations with provincial features like the previously developed "Mulan Cultural Tourism Zone", build new featured tourist destinations, reduce the homogenization of tourist destination construction, make scientific and rational use of tourism resources in Hubei province, and make full use of the geographical advantages of Hubei province at the inland center. Only in this way can the competitiveness of tourist destinations be increased, thus boosting the development of tourism in Hubei Province.

(4) SP Strategies

Hubei province can make use of the government's platform set-up services, so that traditional tourism enterprises can foster strengths and avoid weaknesses, making 'tourism + e-commerce' accelerate the rapid upgrading of tourism industry. The government should vigorously help numerous small and medium-sized tourism enterprises to complete data sharing, and provide support of big data and cloud computing for micro-enterprises, so as to help them carry out integrated marketing, adjust marketing strategies in time, and improve management skills. It helps many enterprises overcome the heavy losses caused by the pandemic and gain the confidence to face difficulties, and at the same time it helps them to be more standardized and pay attention to product differentiation. It makes its traditional tourism keep up with the pace of technological revolution, learn to use the marketing promotion brought by new media, and expand marketing channels. In addition, traditional tourism enterprises and e-commerce tourism enterprises can form a mutually beneficial competition and cooperation relationship by developing O2O-based cooperation.

Summary: The research on this topic mainly analyzed the politics of Hubei tourism development in the post-pandemic era based on SWOT-PEST matrix model, like advantage tourism policy support, geographical location advantage, etc. The economic advantage lies in the gradual recovery of Hubei's economy under the guidance of the government, while the economic disadvantage lies in the overall decline of Hubei's economy due to the impact of the pandemic. The policy opportunities include huge potential consumer market and strong support from the government, etc. The research results in this paper will provide references and feasible suggestions for the development of tourism industry in Hubei province in the post-pandemic era.

\section{References}

1. Wang Guocai. Analysis of Yunnan Tourism Development Based on SWOT-PEST Model. Business \& Economy. 2019(10): 518.

2. Li Wenshan. SWOT Analysis of Yunnan Tourism Development. Tourism Overview. 2017(7): 117.

3. Wang Yanan. Analysis of the Current Situation and Countermeasures of Tourism Development in Yunnan Province. Caixun. 2019(9): 124.

4. Xing Ling, Jiang Sumei. Research of the Driving forces for the Tourism Industry of Yunnan Based on the Method of PEST. Academic Research. 2014(5): 71-75.

5. Li Xiaoyuan. Exploring the Path Towards Tourism Development in Mount Fanjing Based on the Method of PEST. Shangxun. 2020(5.26). 
6. Liu Xiaojing, Zhao Yongfeng. The Impact of Tourism Development on Economic Growth: Empirical Test Based on Improved Cobb Douglas Function. Value Engineering. 2018, 37(10): 76-80.

7. Xu Yang. Research on the Dynamic Relationship of Tourism Development, Economic Growth and Tertiary Industry Growth in Tibet-An Empirical Analysis Based on the Data of Tibet from 1981 to 2015. Tibet's Science \& Technology. 2018(4): $22-25$.

8. Tian Li, Sui Puhai, Yang Yi. Review on Relationship Between Tourism Development and Economic Growth-Based on CSSCI Journals Published in the Past 20 Years. Resource Development \& Market. 2018, 34(6): 862-867.

9. Zhao Xiaojun. An Empirical Study on Inbound Tourism Income and Economic Growth--Taking Shanxi Province as the Example. Technoeconomics \& Management Research. 2019(1): 81-86.

10. Zhang Qian, Wang Liping, Wang Wenbo. A Study of the Dynamic Relationship Between Tourism Development and the Economic Growth Based on Shanxi Province. Journal of Management. 2018, 31(5): 34-45.

11. Wu Qunqi. Regional Differences and Spatial Pattern Evolution of Integration of China's Transportation Industry and Tourism. Technology Economics. 2017(12).

12. Zhan Zhaozong. Analysis of the New Normal of Tourism and Its Enlightenment Based on SWOT-PEST. Zhejiang Academic Journal. 2016(1).
13. Fang Shihao, Lai Fan. Research on the Tourism Development Strategy of Hubei Province in the Post-pandemic Era. Press Outpost. 2020(10).

14. Dai Juan. Research on the Tendency of Convergence and Development of "Transportation + Tourism" Industry in Hubei. Contemporary Economics. 2019(5).

15. Qi Tao. Research on the Relationship between Tourism Industry Development and Economic Growth in Shandong Province. University of South China. 2018.

16. Zhong Liang, Li Zhigang. "Tourism + Transportation" Needs Deep Integration. China Tourism News. 2017-02-21.

17. Huang Fupeng, Wu Li. "Waiting for the Pandemic to Fade Away: Analysis of the Impact of the Pandemic on Tourism in Hubei Province". (2020-05-07). [2020-06-08]. https://mp.weixin.qq.com/s/Mm9mfgzCrojOKJg2K barhw.

18. Gong Jian. Investigation on the Loss, Resumption of Work and Recovery of Hubei Cultural and Travel Industry After the Ppidemic. (2020-04-05). [2020-06-08]. http://cta-wh.ccnu.edu.cn/info/1014/2350.htm.

19. Zhu Kai. An Inquiry into the Impact of COVID-19 on China $\mathrm{s}$ Tourism and Its Countermeasures. Journal of Sichuan Tourism University. 2020(3).

20. National Bureau of Statistics http://www.stats.gov.cn/tjsj/ 